\title{
SUSTAINING EMPLOYABILITY THROUGH LIFELONG LEARNING. A LIFE HISTORY APPROACH TO EMPLOYABILITY
}

ABSTRACT This article presents the practical unfolding of a life history method in a major empirical project on employability. The discourse of employability, seeing the worker as universally adaptive work force, is contextualized historically in a late phase of capitalist modernization. A critical discussion of the prevailing concept of competence for neglecting the subjective dimension of learning and competence development leads to methodological considerations and decisions made in designing this research project, its research questions, its theoretical understanding and the choice of method. Narrative life stories shall illuminate workers' experiences of substantial shifts in their career and the competence development they have experienced in such situations. The article anticipates how a psycho-societal interpretation of life histories can bring valuable insights in the subjective dimension of competence development in the context of workers' life as a whole.

Keywords: Life history. Experience. Competence. Employability.

SUSTENTAR A EMPREGABILIDADE MEDIANTE

\section{A APRENDIZAGEM AO LONGO DA VIDA. UMA ABORDAGEM EM HISTÓRIA DE VIDA PARA EMPREGABILIDADE}

Este artigo apresenta o desdobramento prático de um método de história de vida em um amplo projeto empírico sobre empregabilidade. 0 discurso da empregabilidade, entendendo-se o trabalhador como força de trabalho universalmente adaptativa, é contextualizado historicamente em uma fase tardia da modernização capitalista. Uma discussão crítica do conceito predominante de competência para negligenciar a dimensão subjetiva do aprendizado e do desen- 
volvimento de competências leva a considerações e decisões metodológicas tomadas na elaboração deste projeto de pesquisa, suas questões de pesquisa, seu entendimento teórico e a escolha do método. As histórias narrativas da vida devem esclarecer as experiências dos trabalhadores sobre mudanças substanciais em sua carreira e o desenvolvimento de competências que eles experimentaram nessas situações. 0 artigo antecipa como uma interpretação psicossocial das histórias de vida pode trazer informações valiosas na dimensão subjetiva do desenvolvimento de competências no contexto da vida dos trabalhadores como um todo.

Palavras-chave: História de vida. Experiência. Competência. Empregabilidade.

RÉSUMÉ MAINTENIR L'EMPLOYABILITÉ GRÂCE À

\section{L'APPRENTISSAGE TOUT AU LONG DE LA VIE. UNE APPROCHE DE L'HISTOIRE DE VIE A L'EMPLOYABILITÉ}

Cet article présente le déroulement pratique d'une méthode dans l'histoire de la vie à travers un vaste projet empirique sur l'employabilité. Le discours sur l'employabilité, qui comprend le travailleur comme une main-d'œuvre universellement adaptative, est historiquement contextualisé dans une phase tardive de la modernisation capitaliste. Une discussion critique du concept dominant de compétence pour négliger la dimension subjective de l'apprentissage et du développement des compétences conduit à des considérations méthodologiques et à des décisions prises dans la conception de ce projet de recherche, y compris les questions de recherche, la compréhension théorique et le choix de la méthode. La narration de la vie devrait mettre en lumière les expériences des travailleurs de changements de carrière substantiels et le développement des compétences qu'ils ont vécues dans ces situations. L'article prédit comment une interprétation psychosociale des histoires de vie peut fournir un aperçu précieux de la dimension subjective du développement des compétences dans le contexte de la vie des travailleurs dans son ensemble.

Mots clés: Histoire de vie. Expérience. Compétence. L'employabilité.

RESUMEN SOSTENER LA EMPLEABILIDAD A TRAVÉS DEL APRENDIZAJE PERMANENTE. UN ENFOQUE DE LA HISTORIA DE VIDA PARA LA EMPLEABILIDAD

Este artículo presenta el desarrollo práctico de un método en la historia de la vida a través de un amplio proyecto empírico sobre emple- 
abilidad. El discurso de la empleabilidad, que entiende al trabajador como una fuerza laboral universalmente adaptativa, se contextualiza históricamente en una fase tardía de la modernización capitalista. Una discusión crítica del concepto predominante de competencia para descuidar la dimensión subjetiva del aprendizaje y el desarrollo de la competencia conduce a consideraciones metodológicas y decisiones tomadas en el diseño de este proyecto de investigación, incluidas las preguntas de investigación, la comprensión teórica y la elección del método. La narración de historias de vida debería arrojar luz sobre las experiencias de los trabajadores de cambios sustanciales en su carrera y el desarrollo de habilidades que experimentaron en estas situaciones. El artículo predice cómo una interpretación psicosocial de las historias de vida puede proporcionar información valiosa sobre la dimensión subjetiva del desarrollo de habilidades en el contexto de la vida de los trabajadores en su conjunto.

Palabras clave: Historia de vida. Experiencia. Competencia. Empleabilidad.

I have had several occasions to present the results of life history research in adult education and learning for Brazilian colleagues through CIPA and the two collections published by Abrahão (2004; 2018). I am deeply grateful for the great work on editing and translation into Portuguese, which has been carried out in this context, including a recent account of the development of this research (OLESEN, 2018). This work places particular emphasis on the development of a psycho-social analysis of biographical material, but at the same time it is emphasized that this methodological development has always been driven by a problem-oriented epistemology: The method has been further developed through research in mundane social sectors with a view to understanding the actors in these areas, including special professional practices in teaching, socially work and health promotion, and give rise to a dialogue on the political and moral aspects of their practices.

In this article, I will present the practical unfolding of a life history method in connec- tion with the design of a major empirical project which has just begun in Australia under the leadership of Professor Stephen Billett. My role in this project is to contribute to the methodological design of the project with a life-history analysis framework and to participate in the unfolding of the project throughout the threeyear project.

I would like to elucidate the crucial strategic considerations and decisions made in designing this research project on its research questions, its theoretical understanding and the choice of method. I will first quote a summary of the project description, in page (number):

The proposed project aims to generate evidence-based policies and informed practices to support accessible work-life learning arrangements that promote the employability of Australian workers. Employability is more than securing employment: getting a job. It includes having the abilities to remain competent, thereby resisting unemployment (i.e. sustain employment), and being able to secure advancement, broadening occupational roles, or adapt to new 
circumstances and practices (i.e. developing a career). Securing those capacities equates to what is often referred to as 'lifelong learning' or 'learning across 'working life', which is of interest to governments, workplaces, professional bodies and workers as well as to those whom they provide goods and services. (BILLET, 2018, p. 1).

The project has its point of departure in the concept of employability and aims to find out how to support the opportunities to maintain employability through learning and education. The people whose employability research is about appear indirectly, as stakeholders who, along with virtually everyone else, have an interest in this research. But the epistemic object is not the people as such but their societal status as wage workers and bearers of this employability. This immediately understands the demands of the labor market as an independent driver for the learning processes needed to be employable. However, the focus of the study is not the development of work and its demands on the labor force, but a study of what it takes for working people to be able to keep up with them - or in the words of the project proposal: "how promoting that employability can be realized by identifying and verifying the types of experiences that most effectively and viably support learning through informants' everyday work activities and educational provisions ". And this is not a narrow or static concept of employability: "It includes having the ability to remain competent, thereby resisting unemployment (ie sustain employment), and being able to secure advancement, broadening occupational roles, or adapt to new circumstances and practices (ie developing a career)". The worker must therefore live up to the demands of the labor market, but not in any uniquely determined way.

The problem of the study is obviously determined by something that appears to be a general political theme in most capitalist countries: competence development through lifelong learning is seen as an instrument or prerequisite for economic development and competitiveness. This societal view generates a social engineering challenge of clarifying the means that enables workers to adapt to the differentiation and change of work, and thus maintain their individual value in the labor market. But research that can contribute to this social engineering must shift the perspective and see the workers as learner subjects, who develop their competences from their subjective perspective. to the In this article I will take a critical view on the concept of competence used in the discourse on lifelong learning, and raise the question: Can we, through empirical studies of how concrete people actually handle the changes of (paid work) life, gain theoretical insights into the dynamics of lifelong learning and competence development? How can we do that? These questions of learning theory and methodology that makes the project very promising.

\section{The context of the study}

The practical issue of the Employability project is a symptomatic result of a historical change in societal structure. The development of capitalist modernization has, above all, entailed a constant change in technology and business structure. In pre-capitalist societies, society is relatively stable from generation to generation - the location, the technical and procedural content of the work, the division of labor, etc. constitute a stable framework for the learning processes of growing up individuals. Culture and normative orientations do not change much over a generation. In such a society, the upbringing has the character of social adaptation to well known conditions, and education has the nature of disseminating recognized practices and knowledge. Compe- 
tence development is a marginal growth within known frameworks. Modernization means that there must be an accelerated transfer of skills between the generations. This task is left to the school and later also an increasingly formalized vocational training for young people: Children and young people are taken up to society's "current cultural stage" until adulthood. The increasing importance of the education system can initially be seen in response to the need to ensure dissemination to all, and gradually more and more to a demand for temporal compression of this dissemination.

This trend has continued, but through the industrial modernization, the relationship between generations and societal change has changed so that the relationship between the period length of the cycles has become almost the opposite. Before, many generations passed on a societal epoch - Now there are several constellations of society going on one generation. You can discuss what constitutes societal epochs - hardly every new technological innovation can be seen as an epochal change, but many of them require learning - and each generation experiences a few changes that can be called epochal changes. In addition, the modernization process has led to a number of cultural and social changes that give both learning and work new subjective meanings. Not only is lifelong learning a societal requirement, but it has also become a central component of many people's everyday lives and life strategies. Individualization is a direct cultural consequence of the modernization process, also seen as a cultural release (ZIEHE, FORNÄS, \& NIELSEN, 1989).

I use the concept of modernization as a term for the comprehensive transformation of society and culture that concerns both culture, institutions and the individual, driven by capitalist industrialization in the capitalist center of Europe and North America. I do this to maintain the basic nature of the process, even though it is not a smooth and homogeneous process - it proceeds widely differently and not least, one can rightly distinguish between "center" and "periphery", and globally between a "northern" and a "southern" version of this modernization (CONNELL, 2007; SOUSA SANTOS, 2014). Knowing that the historical process differs in different variations and phases, the concept of modernization provides a framework to explore empirically how the historical transformation of society has an impact on the life of the individual, and that is precisely what the employability project allows.

Once upon a time profession was a form of life that was relatively given and characterized a person's life completely. The normal biography consisted of one professional career with pre-education and post-retirement, and one accompanying family career that, mediated through the gender division of labor and the core family, was linked to the professional career. As a consequence of modernization, a profession becomes more and more something that is chosen and 'held' - not freely, far from tha - but work identity is something that is formed by occupational choice and changes with actual employment and occupational changes. It can be said that wage labor is increasingly shaping the work identity in the sense that work ability becomes a de-personalized commodity that can be acquired and exchanged as such.

The same goes for women. Women now work in the formal economy almost all their adult lives, interruptions in childbirth are quite short-lived. Both sexes are gradually gaining a working 'career' which means that women are not merely a buffer in the geographical and practical working conditions of men, and are not tied to a partner for life. Both careers undergo shifts and loops, and professional and personal needs are merged in a new way. 
In spite of the fact that social normativities and established cultural horizons have been eroded in the course of modernization process they still play a significant role in the form of class and gender orientation patterns, and each individual must throughout adult deal with the reconstruction of these cultural universes, building their own matrice of a life course. Let us focus on gender.

Regina Becker-Schmidt, with her concept of "Geschlechterverhältnis", has termed the fact that gender relations form a structural component in capitalism and also encapsulates the core contradiction in capitalist social formation ((BECKER-SCHMIDT \& KNAPP, 1987a, 1987b): On the one hand women's participation in the formal labor market as (almost) equal wage workers enables a universal commodification of socially necessary work. On the other hand the physical and social reproduction of society is (still) dependent on women's work and femininity as social competencies. Changing gender relations in general and women's work activity are directly linked to general shifts in the occupational structure from manufacturing to service industries, and in particular to the care sector (childcare, elderly care, nursing). In these growing professions, personal characteristics and competencies play a greater role in working practice than in manufacturing industries. In a broad sense, this trend means blurring the boundary between professional qualification and personal development, and takes on much more variable forms than before - both between different individuals, generations and genders, and across the adult life of the individual.

The changing gender relationship that we see evolving in many forms is also seen as part of the restructuring of capitalism, and in this respect the understanding of gender relations in work are also politically contested, for instance in a memorable discussion between
Nancy Frazer and Boaventura Sousa Santos the relationship between capitalism, patriarchy and colonialism. Where Santos asserted the relative independence of each of the structural power relations, Frazer's reasoning was an emphasis on the inner coherence between capitalism as the basis societal relation and patriarchy and colonialism as the derived forms of coercion. In all simplicity, this theoretical discussion proposes an empirical-historical examination of the relationship between ethnic identity, work identity and gender identity in individual lives. Studying empirically the learning processes related to work identity in connection with career changes we get a micro level peep hole into the subjective dimensions of such basic societal developments. The two trends pointed out here, the basic change in work and family career once or more in adult life, and the increased interplay between professional identity and personal development are both connected with changing gender relations. They imply that the personal development of the adult person has an increased impact on work identity and learning in connection with work. Complicated shifts in people's lives can be both the trigger for and sometimes the result of extensive and in-depth learning processes. Sometimes in the form of participation in education, other times not. Continuing education in adulthood often takes place in these particular stages of transition, and education often has more complicated implications than just its explicit purpose. Lifelong learning is thus far more comprehensive than a continuous refueling exercise.

The concept of employability must be seen in this context. Occupational change is a condition of life and the fact that several societal technology and business changes are going on in a single generation of working life means that people must try to keep up with changes. The basic education system is no longer a 
guarantee of lifelong employability - more and more people are changing occupation area in a way that either involves a new qualification or a re-functioning of the competences that the individual brings. But changing occupation and changing work requirements is not just a professional retraining. By seeing this in the context of modernization and the ongoing restructuring of the social form of industrial capitalism, we also gain a deeper understanding of the connection between challenge for maintaining individual employability and the ongoing restructuring of the societal form of industrial capitalism.

The interest in employability is thus a symptom of a societal transformation which means that people must constantly be able to undergo fairly basic developments and that the school and education system that has tried to equip the individual with a lifelong knowledge and skills base can no longer fulfill this task alone. Therefore, in order to elucidate how employability can be maintained, we must deal with the totality and coherence of individual learning, formal as well as informal. In schools as well as elsewhere.

\section{Theorizing competences}

These societal conditions have paved the way for a new framework for discussion of learning and a new vocabulary which is not related to formal education and schooling but rather to the capabilities in relation to work. It has flipped the lens from teaching to the individual learner in context, from curriculum to learning outcomes, from knowledge and skills to competences. It is not a development which is fostered in education, on the contrary many educators see these discourses as a farewell to education as such, in the sense of "Bildung".

The new descriptor for human capability is competence (NICOLL \& SALLING OLESEN, 2013;
SALLING OLESEN, 2013a). Originally the concept of competence had a legal meaning related to legitimacy. The meaning that gained ground from the 1990s combines functionalism and psychology, where the emphasis varies a little between the two and which has been applied in different ways (GNAHS, 2007; ILLERIS, 2009; D. S. . RYCHEN \& SALGANIK, 2001). Nevertheless, there is in practice today a core meaning: competence refers to the abilities of an acting subject to translate knowledge into appropriate action for everyday practical situations, above all in work processes. This ability can be specified in the following attributes according to Rychen; Salganik (op. Cit,), 2001, and summarized by us:

- The ability to act successfully

- In a complex context

- Through the mobilization of psycho-social prerequisites (cognitive and non-cognitive)

- With results related to the requirements of a professional role or personal project

In this understanding, which is representative of the political-economic use of the term, competence is in one respect functional, performance-oriented and pragmatic, and defined in terms of external social demands that need to be mastered. Additionally, it also involves a questioning of previous conceptions of the application of knowledge, where knowledge is something one can have and where rational practice can be based on general abstract knowledge. "Competence" is addressing practices that are not fixed and known beforehand, and in competent practice knowledge must be mobilized and transformed in order to be applied successfully. Therefore, competence is linked to a potentially acting subject who is able to mobilize various prerequisites in a manner relevant to the situation at hand. 
Competence has been applied in an effort to identify the qualities of the workforce that are vital for the economy and competitiveness, key competences, and were intended to serve as a guideline for national policies for long term competence development, while also serving as a general equivalent (SALLING OLESEN, 2014) enabling some kind of calibration for comparing the workforces.

In the OECD DeSeCo project (Definition and Selection of Competencies) this analytical task was approached quite ambitiously. The scientific project to create clarity and consistency in the definition of key competences was obviously triggered by the pragmatic desire to achieve workable indicators of generic competences for policy making and international comparison. One of the experts, the psychologist Franz Weinert, referring to the connection between competences linked to specific practices and key competences with broad or universal applicability, states as follows:

[...] such scientific plans have often failed in psychology, however. The underlying multilevel models can be logically reconstructed, but not validated psychologically. The different degrees of abstraction mean, therefore, a fundamental asymmetry in competence research - high abstraction: intellectually brilliant, pragmatically hopeless; low abstraction: pragmatically useful, intellectually unsatisfactory. (WEINERT, 2001, p. 52).

To put it simply: The scientific ambition to understand the dynamics of subjectivity must be sacrificed in the pursuit of pragmatic policy needs.

I think the difficulties involved in such use can be related to two conceptual problems, both enforced by the political context in which the concept was conceived and propagated. One is reification or commodification, i.e. it is assumed that competences are immutable properties that can be acquired and pos- sessed. This reification is directly triggered by objectives of measurement and comparison, but also in the thinking of economists regarding the logic of the market (commodification) and capital (accumulation). The definition and description of key competencies seem to be driven by a dream of a universally flexible and adaptable workforce in an era where the industrial (Taylorist) division of labour and its way of reducing the complexity of work tasks operations is becoming outdated.

In the above summary definition of competence the two first items clearly refer to a future more complex work situation. In the $3^{\text {rd }}$ item the attention is drawn to the necessary endeavour of mobilizing "cognitive and non-cognitive" prerequisites. This attempt for a psychological conceptual delineation revolves around the relationship between cognitive factors, which are well defined, and a great many other things that can only be defined negatively, as non-cognitive, but seem to include motivational and other emotional factors. Within a cognitivistic figure of thinking and learning, which seems to be the starting point, it is the relationship between universality/abstraction and specificity/concreteness that challenges the conceptualisation, since practical problem solving and agency involves something more than abstract knowledge. Weinert himself also refers to empirical data showing that the solution of difficult problems always requires the involvement of content-specific knowledge and skills (Weinert, 1998). In his psychological contribution to the DeSeCo project's initial conceptual process, Weinert emphasizes that competence implies and presupposes, in the fulfilment of a task, a combination of 'cognitive and (in many cases) motivational, ethical, volitional, and/or social components' (D. S. RYCHEN \& SALGANIK, 2001, p. 62).

This leads us to the second problem of the prevailing competence discourse, namely that 
it does not take the subjective nature of competences seriously. In spite of assuming that the nature of practice is unpredictable and will require more and other than cognitive prerequisites, but these factors add to the complexity of the specific tasks on which the competent agent can act successfully, however independent of the specific agent subject and his/her relation to the practices in question.

This is fatal for the understanding of competence, and particularly the dynamics of developing competences - i.e. learning. Although the requirements or success criteria for competent practice are externally determined, competent actions are basically subjective processes, based in feelings and interpretations: problem comprehension, impulse for practice, mobilization of knowledge, learning, and practising skills in new contexts. These subjective or "non-cognitive prerequisites" to use the DESECO vocabulary - are result of life experiences and previous learning. The concept must involve a view of competence as a personal, culturally anchored and experience-based capacity, located in the competent person's way of interpreting situations and engaging in them, and also as a tool for learning. It must seek to understand the subjective "productive forces" that may lead to learning and practice development, including those involved in the emotional and cognitive work of detachment and reconfiguration of experiences. It must enable analyses of the complexes of rationality and defence mechanisms, rooted in the life experience, from the interaction with family, leadership in community etc. They may in a professional career be redefined by professional knowledge - but when, how and why still underpinned by personal life experience.

This will require that we overcome the reification/commodification of competences. Only if we recognize this subjective dimension of practice we enable an empirical investigation of the relation between those aspects of competence that were only negatively defined, the "non-cognitive psychosocial prerequisites", and the life experience and learning of the practitioner - which are individual, situated and changeable. For the sustaining of employability it becomes obvious that employability will depend on identification of the worker with the specific work process and its content - not as a general attitude only, but as a specific compliance with an individual and collective life experience.

The research which is just commencing in Australia is defined within a framework of competence development, integrating learning through formal education and training as well as informal learning. In the words of the project proposal:

Here, th[e] aim is to understand further how promoting that employability can be realised by identifying and verifying the types of experiences that most effectively and viably support that learning through informants' everyday work activities and educational provisions. Using retrospective cases, firstly, [...] (BILLETT, 2018, p. 1).

In order to avoid some of the conceptual problems which arrive in the prevailing theorization of competence, as described above, we will work with a life history approach. Leaving the following steps of the research away for a moment, and also the promises for social engineering, I will explain how this will happen. The first phase of the research will explore retrospectively the learning careers that have for a number of interviewees enabled them to maintain employability in a changing environment. The sample will be relatively small ( 24 individuals) and they will be selected so as to cover a variation of occupations, age, and gender - all however characterized by obvious shifts in their working career - either triggered by structural changes in labor market, by specific developments of work processes and 
occupational structure, and/or by their own decisions. They will be interviewed in a two step procedure, first a very open narrative autobiographical interview, and second a follow up where researchers on the basis of a preliminary analysis will clarify facts and circumstances that seem of importance and invite the IP's to reflect on their learning career so as it stands out from their narration.

The project design further includes a longitudinal shadowing of interview persons' later learning in the form of "detailed progressive accounts secured through year-long shadowing of workers' learning through discussions and observations, informed elaborations of processes of work-life learning, effective forms and sources of support for that learning will be identified and appraised. (BILLETT, 2018, p. 1)".

We have chosen an autobiographical interview for two reasons. First, because we want to give voice to the protagonists themselves, we want to apply an inside perspective on the subject-matter. Interview persons will be encouraged to tell their entire life story, with just a minimal indication of our particular interest in learning and career shifts. Second, an autobiographical interview has specific qualities as a told story and in text resulting from its transcription because the narration obeys cultural rules or standards of interaction that may or may not be conscious for the narrator. A narrative account is more than a naked transmission of information about what has happened and what has been. It is also not a purely intention-driven agency (illocutionary speech acts). Actually our two reasons for choosing this method converge in the sense that a narrative as a specific form of language invites but also presupposes a subjective engagement and a legitimate focus on the narrator as a subject irrespective of the circumstances and the research project. The precondition for this is that the research interviewer succeeds in defining and facilitating a compliance about the narrative communication.

A good autobiographic interview requires certain relational and technical precautions: The research interviewer must of course be genuinely interested in the interview person as a subject, not as a token and not as a "source" for information about history or the societal whole ((BERTAUX, 1981). He/she must be able to create a confident atmosphere, and he/she must be able to maintain this line of communication in a supportive encouraging and self-restrictive way of pushing the narration ahead. The qualities of the narrative as a specific form of text can be related to a number of cultural standards or rules that can be summarized as "requirements" that a narrative has to fulfill or obey. These requirements are in some ways recognizable as aspects of literary tools although they are of course released from aesthetic evaluation.

Storytelling must be concrete and detailed - it must have a point or morale, but it must also expand, complicate and provide details which enables imagination and possibly suspense. The point of the story must be motivated, have a relevance and must condense a wider meaning and perspective. Having adopted the narrative compliance this also means that the story must saturate and complete the line of incidents and the logic of the situation. Obviously the fulfillment of these requirements can be more or less consequent in each case but it is expected that we can gain a very rich empirical material, which with an appropriate analysis will enable a deep understanding of the life experiences of interview persons.

\section{A hermeneutic method: the concept of Experience}

When (auto)biographical research is used in sociology or history research it is often pre- 
ferred in order to understand society and history from a life world perspective - oral history, cultural studies of collective memory. In a symbolic interactionist framework you may assume a high level of homological structure between the narrative and the agency in the time and situation told - the autobiographical narrative is as close as you can come to reproducing the meaning making of the persons in the story. In this sense autobiography is lifelike. But still it is necessary to remember that the (auto)biography is "only" a text or a speech act in the present. It presents an interpretation of the lived life told by someone who is on the one hand part of it but on the other hand is already somewhere else, seeing the agency of the told time in the light of his or her present context and not least imagination of the future. The biography he or she tells is interesting both as an account of the past and an expression of the present subject in his or her present situation (and actually we must understand the self-interpretation in the present in the context of the present and anticipated future employment condition). This complexity is not different in principle from any interpretive understanding - but it is particularly important in autobiographical research because the fact that he or she is doing the account of him-/ herself may nourish an illusion of authenticity and truth, which again goes together with an epistemological problem of social science in general, namely the illusion of an identical object. (ADORNO, 2001). You may radicalize this view into a constructivist view, which is sometimes the case in learning research so that the narrative produced in the interview is in itself the object of research. This is not the epistemic interest in the Australian project.

Seeing the autobiographical narration as a subjective action in itself is also an interpretative condition in this project. But we ultimately want to understand how interviewees have in the past interpreted their real life conditions - particularly in relation to employment - and have been able to sustain their employability. There is a double level of interpretation: we must extract an understanding of the past subjective agency through the later (self)interpretation, but we also need to relate it to objective conditions of work, labor market and the objective employability in the past of the interview person. Although we can, and we will seek to align this with other sources of knowledge about work and labor market context, we must be aware that the agency of the IP at the time have been based on their own more or less realistic assumptions and interpretations, and we may investigate which circumstances have shaped the subjective ideas about context. In the design of this first phase a second interview round will give the chance for an interpretative loop in which first interpretation can be in some respects tested and corrected, but primarily enriched by the second order reflections of the interview persons in the second interview round. The purpose of this will not be to check if we got the correct account, or if the IP had interpreted his situation appropriately, but to improve our understanding of the dynamics of the experience process.

The dynamics of learning processes are not purely cognitive - their complexity, unpredictability and diversity are linked to emotional engagements, resistances and entrenchments that give them a certain direction, sometimes hinder them, etc. Societal, historical relationships are subjective processes - knowledge as well as learning are both socially and physically mediated. Which new experiences and challenges will become learning opportunities and which do not depend on a concrete interaction between the social framework of everyday life and life-history experiences, mediated through the individual learning body and consciousness. 
The longitudinal dimension - and its unpredictability and individual specificity - is absolutely crucial to what is the theme here: How do learning processes and identity formation in a new career build on past life-history experiences and resources? We do not seek causal explanations or regularities. The goal is not to predict who can and will what, but to understand what people actually do or have done in the light of their past experiences and living conditions.

\section{Psycho-societal interpretation}

In order to extend and enrich our understanding of how past life-history experiences are conveyed in contemporary subjective meanings and identifications, we can incorporate concepts from socialization theory and social psychology (LEITHÄUSER, 1976; WEBER, 1995, 2002; WEBER \& OLESEN, 2001; WEBER \& SALLING OLESEN, 2002).

In previous research we have developed an 'in-depth-hermeneutic interpretation', which is basically an ordinary hermeneutic interpretation of cultural symbols and activities but integrates some experiences from psychoanalytic interpretation, in order include also unconscious dynamics in the text object of interpretation (a text, an interaction) and in the interpretations procedure itself. It understands subjectivity as an aspect of everyday life interactions, including not least work and work-related learning processes, and also give rise to a methodological reflection of the research subject's involvement in the interpretation (SALLING OLESEN, 2013, 2017, 2019). The real life history merges the emotional and cognitive processes to a person's bodily and social practices, interacting with cultural frameworks and societal conditions.

Theoretically, it refers to the material socialization theory formulated by Alfred Loren- zer and forming the basis of his development of the in-depth hermeneutic interpretation of cultural meanings and artefacts (LORENZER \& KÖNIG, 1986). The focus of socialization theory is on early socialization and, like other "modern" psychoanalytically inspired theories, sees the basic psychological development of an individual as a result of the child's early experience of the "world". This goes through the necessary interaction with the child's caregivers, primarily the mother. The "mother" is the central safeguard of the dependent child's well being in this context the corporeal representative of "the social", and the interaction experiences are "inscribed" in the child as traces of interaction forms, ie. practices that have later become differentiated. Although these interactions are naturally structured by societal and cultural conditions - for example, through the "mother" 's class-specific relation to work - it is an individual experience. The special feature of Lorenzer's theory is that it attributes, in particular, the acquisition of language to a crucial importance for this differentiation. The practical experiences are symbolized, ie a connection is established between the sensory (individual) experience and a culturally accessible language game (subject, knowledge). But it is also important that far from only successful forms of interaction are inscribed, it is also traces of "systematically broken practices" that cannot be integrated. A retrospective analysis of learning will most likely also find defensive barriers and staggered motives interfering with a person's emotional and cognitive ability to navigate social demands, thus blocking learning and constraining employability.

The understanding of subjectivity as a result of life-history interaction experiences characterized by conflict-filled societal conditions led to a problematization of the notion of a bounded and coherent subject. Instead, the subject is seen as a process of experience, 
inner encouragement and changing social practices. The autobiography produced here and now is an articulation of the subject's own understanding of this process, and it relates retrospectively to social conditions. It is articulated through a cultural medium (the narration) and in a particular situation and can, with some reason, be called a temporary identity. It is a conscious process but it is the result of a process that has both conscious and unconscious dimensions.

Employability is a subject-object relationship. The demands of the labor market and the change in them are one of the central social conditions that contribute to the formation and transformation of the subject, and the formation of a worker's identity implies a more or less clear identification with the requirement of employability. Maintaining employability within a universe of capitalist economics and wage labor is a central dimension of subjective life experience that has a high degree of learning. We call it learning when the individual through this process increases his/her practical and reflexive capacity, ie. His/her power and insight into the objective world in which the subject lives, but also his/her understanding of himself, and thereby his ability to express own needs and impulses. But it is crucial that it forms part of a whole body of life experiences, emotional orientations and resultant motives that also include other aspects of life, and which places the importance of work and employability in an overall identity context, which includes, for example, the relationship between gender identity and work identity.

The use of the in-depth hermeneutic interpretation, or psycho-social interpretation, is a way of understanding subjectivity as expressed in actions and utterances - for example, the autobiographical interview - as tangible and unique intertwining of the individual's concrete life experience - both in the present and past, and with the future in mind - and the cultural and material environment. In the context of this project, we will use them to study the transformation of specific experiences and competencies over the interviewees' past lives, thereby maintaining their employability - with variation in degree and the way in which they maintain it. Individuals have changed their employability both in terms of their objective opportunities in the labor market and in the workplace, and in the significance of work for themselves (their work identity).

\section{Career Shift and Competence Development}

The connection between the societal level that is codified in business areas, professions and jobs and the life-history experience and identity is absolutely crucial to our understanding of career changes and the particular learning processes involved in them. Maintaining one's employability under changing conditions often requires that you learn something new, but in particular that you are able to utilize your skills in a new way. I prefer to avoid the concept of transfer for two reasons. On the one hand, the concept of transfer indicates that there are some entities - knowledge, skills, etc. - that can, so to speak, be moved from one context to another, without itself changing - ie a conceptual commodification. On the other hand, one cannot just look at the elements that are "transmitted", one must also focus attention on the context that makes it possible or impossible. Instead, we have used the concept of reconfiguration of experiences, which may not be much better, but hopefully unaffected by the reification that the concept of transfer entails. In this sense, it logically attaches itself to the emphasis on subjective expression and practical implementation that the concept of 
competence contains, but also has difficulty in unfolding.

In understanding what "re-configuration" involves, we can refer to Lorenzer's theory of socialization and its understanding of interaction experiences. It is a peculiarity of interaction experiences that they with a concept from psychoanalysis are scenic, i.e. sensory perceptions of the world encompassed in a holistic context, being bodily present in the scene which for the child a total dependency. None of the elements in the situation can be seen independent of the whole and the experience of the little child is thus in this sense a scenic experience. With language acquisition, the child enters the social world - conceptualized with Wittgenstein's concept of language games. The child establishes symbols, i.e.. connections between the forms of interaction that are at the heart of the past experience, and linguistic expressions whose meaning is given from the outside, through the social interaction that has formed the cultural significance universe of the language game. Initially, language acquisition is holistic, non-differentiated, but gradually meanings become more differentiated. Symbolization implies establishing a close connection between all sides of the sensory memory (feelings, relationships, observations, actions) that were part of the scenic whole and linguistic expressions which, in turn, have a meaning core that is somewhat socially defined but also has an implication, which all other language users associate with them based on their experience background.

The symbolization's connection between the scenic experience and language (symbolization) that - mutatis mutandis, with relevant adaptations - provides a framework for an understanding of the interaction between the relational and emotional aspects of life experiences and the linguistic cognition that is central to reflection and in most learning process- es. On the one hand, we see it as an indication of how the different sides of learning and identity formation are interwoven in the subjective development process. On the other hand Lorenzer's tangible materialism gives an indication of how "society enters the body" through individual interaction experiences and shapes dynamics that remain active later in life. This provides a frame for understanding how social interaction later enables very large and sometimes fractional reinterpretations of past life experiences. These changes are not the same for all individuals in the same social universe, nor are they determined - they can only be understood from behind. It is the ultra-brief rationale for empirical work with them.

We need to understand competence in the context of life experience, and competence development as an element in an individual identity development. To understand this context, we must firstly incorporate fundamental social experience backgrounds such as social class, gender and ethnicity as preconditions for a cultural identity, but also the subject's individual understanding of his or her own role in existence, as can be read from the autobiographical narrative: he understands / herself as the governing body in life, or as a product of certain factors in the environment, even as a victim of fate (ALHEIT \& DAUSIEN, 2002; ANDERSEN, DAUSIEN, \& LARSEN, 2005; SCHÜTZE, 1984). It is crucial to conceptualize identity as a subjective act, an identification process, rather than as a cultural imprint of social influence, and it is crucial to recognize the procedural and probably ambivalent nature of identity. (WEBER, 1998; WEBER \& SALLING OLESEN, 2001). But we may achieve a more concrete differentiation of the social relations class, gender and ethnicity and their actual interweaving (intersectionality) by interpretation of individual cases. Becker-Schmidt contributed concepts of women's dual socialization and women's 
work as an ensemble of different kinds of work (BECKER-SCHMIDT, 1982, 1991, 2019; BECKER-SCHMIDT \& KNAPP, 1987a). Martin Baethge uses the notion of life concept to differentiate between work orientation, family orientation, and leisure orientation. And in a larger empirical study of young people's form of work orientation he distinguishes between work as concrete life activity, subdivided into self-realization through work content or a primary orientation towards social relations at work - and on the other hand work as instrumental activity, subdivided between orientation towards income and employment security and an orientation more toward career and social status (BAETHGE, 1994; BAETHGE, HANTSCHE, PELULL, \& VOSKAMP, 1988). These empirical categories can be used to specify the identity of class and gender, and in this way help to spot the small changes and ambivalences in the overall categories. In the area of work identity, one can further try to identify specific work activities and forms of engagement in them. Professional identification can be seen as a subjective identification that presupposes autonomy and accountability at work, and in Baethge's sociological categories intersecting between commitment to work content and the social status.

The intention is primarily to show the need to integrate categories for the social dimensions of life experiences with the idea of the subjective experience process as it is theorized in the section on learning processes and experience. Again, it is crucial to examine the complex nature of skills development and careers at the level of everyday life, taking into account individuals' past life experiences in relation to the overall societal categories.

\section{Conclusion}

By choosing the autobiographical interview, we hope to gain a complex empirical input to understand how the interviewees have interpreted their reality and maintained their employability through learning. In the interpretation procedure of the life history approach, we obtain a key to understanding the complex context of learning processes with the 'scenic' nature of experience and the language game as the access to social knowledge and meaning (SALLING OLESEN, 2012; SALLING OLESEN \& WEBER, 2012). All the knowledge, skills and attitudes we carry with us are embodied combinations of emotional, cognitive and actionable practices that are interwoven in the scene that experience captures and processes. Learning is very much experimental and reflexive reconfigurations of elements of these life experiences that detach them more or less from one subjective configuration and establish them in another, linked to a new practice. Competence In the sense we are talking about here, there is a potential for situational mobilization of mental and bodily resources - which can result in a learning process that produces a new competence, ie. stabilizes the immediate availability of these resources which increases the potential in future situations.

Through a deeper understanding of the dialectic of past interactions with material life conditions in which our interview subject have been (more or less) able to sustain their employability we hope to get an insight in how others may be supported in sustaining theirs. Gaining knowledge that can support policies, education and training measures, and hopefully also individuals in their own career planning form the practical perspective of the research.

\section{References}

ABRAHÃO, Maria Helena Menna Barreto (Org). A Nova Aventura (Auto)Biográfica -Tomo II. Porto Alegre: EDIPUCRS, 2018.

ABRAHÃO, Maria Helena Menna Barreto (Org). A 
Aventura (Auto)Biográfica: teoria e empiria. Porto Alegre: EDIPUCRS, 2004.

ADORNO, Theodor Wiesengrund. Negative Dialectics. Berlin: Alemanha, 2001. Retrieved from www. efn.org/ dredmond/ndtrans.html.

ALHEIT, Peter; DAUSIEN, Bettina. The "double face" of lifelong learning: two analytical perspectives on a "silent revolution." Studies in the education of adults, 34(1), 2002. p. 3 -22. Retrieved from http:// www.worldcat.org/oclc/425480992. Accessed in: 10/11/2019.

ANDERSEN, Anders Siig; DAUSIEN, Bettina; LARSEN, Kirsten. (Orgs). Livshistorisk fortælling og fortolkende socialvidenskab. Frederiksberg: Roskilde University Press, 2005.

BAETHGE, Martin. Arbejde og identitet hos unge. In: SALLING OLESEN, Henning. Arbejde og subjektivitet. Roskilde: Erhvervs- og Voksenuddannelsesgruppen. Virhorh: Erhervs - Roskilde Universitet, 1994. p. 227248.

BAETHGE, Martin, et alli. Arbeit und Identität. In: WESTDEUTSCHER Verlag; BECKER-SCHMIDT, Regina (Orgs.). Modsætningsfyldt realitet og ambivalens:kvinders arbejdserfaringeri fabrik og familie. Udkast: (s/e), 1998. p. 164-198.

BECKER-SCHMIDT, Regina. The relevance of biographical studies for empowerment strategies. In: SALLING OLESEN, Henning (Org.), The societal unconscious. Rotterdam/Boston: Brill/Sense, 2019. p. 61-74.

BECKER-SCHMIDT, Regina. Continuity and discontinuity in women's life courses. In: HEINZ, Walther (Org.), Theoretical advances in life course research. status passages and the life course. Weinheim: Deutsche Studien Verlag, 1991, s.p.

BECKER-SCHMIDT, Regina; KNAPP, Gudrun-Axeli. Die doppelte vergeselschaftung - diedoppelte Unterdrückung: Besonderheiten der Frauenforschung in den Sozialwissenschaften. In: UNTERKIRCHNER, Lilo; WAGNER, Ina (Orgs.). Die andere Hälfte der Gesellschaft. Wien: Verlag des Österreichischen Gewerkschaftsbundes, 1987a, s.p.

BECKER-SCHMIDT, Regina; KNAPP, Gudrun-Axeli.
Geschlechtertrennung - Geschlechterdifferenz. Bonn: Verlag Neue Geselschaft, 1987b.

BECKER-SCHMIDT, Regina. Modsætningsfyldt realitet og ambivalens: kvinders arbejdserfaringer i fabrik og familie. Udkast, (n/a), 1982, p. 164-198.

BERTAUX, Daniel. Biography and Society: the Life History approach in the social sciences. Beverley Hills: Sage, 1981.

BILLETT, Stephen. Pratices and Policies for Sustaining Employability across Work-life through Lifelong Learning. Research Project, 2018.

CONNELL, Raewyn. Southern Theory: Social science and the global dynamics of knowledge. London: Polity Press, 2007.

GNAHS, Dieter. Kompetenzen - Erwerb, erfassung, instrumente. Bonn: DIE, 2007.

ILLERIS, Knud. (Org.). International perspectives on competence development. London:

Routledge, 2009.

LEITHÄUSER, Thomas. Formen des alltagsbewusstseins. Frankfurt/Main; New York: Campus Verlag, 1976.

LORENZER, Alfred; KÖNIG, Hans-Dieter. Tiefenhermeneutische kultur-analysen. Frankfurt: Fischer Taschenbuch Verlag, 1986.

NICOLL, Katherine; SALLING OLESEN, Henning. Editorial: what's new in a new competence regime? Forum: qualitative social research. (2), p.103-109. setembro, 2013,

RYCHEN, Dominique Simone; SALGANIK, Laura Hersh (Orgs.). Defining and Selecting Key Competencies. Seattle/Toronto/Bern/Göttingen: Hogrefe \& Huber, 2001.

SALLING OLESEN, Henning (Org). The Societal Unconscious. Rotterdam/Boston: Brill/Sense, 2019.

SALLING OLESEN, Henning. Da pedagogia à investigacão em história de vida: um giro em direcão à interpretacão psicossocial. In: ABRAHÃO, Maria Helena Menna Barreto (Org.). A nova aventura (auto) biográfica - Tomo II, 2018. p. 97-129. 
SALLING OLESEN, Henning. A psycho-societal approach to life histories. In: GOODSON, Ivor et alli (Orgs). The routledge international handbook on narrative and life history. London: Routledge, 2017. p. 214-225.

SALLING OLESEN, Henning. The societal nature of subjectivity: an interdisciplinary methodological challenge. Historical social research-historische sozialforschung, 13 (3), p. 7-25, 2013.

SALLING OLESEN, Henning. The societal nature of subjectivity: an interdisciplinary methodological challenge. A psycho-societal approach in empirical social research. Forum: Qualitative Social Research Sozialforschung, (3), p. 1-17, setembro, 2012. Retrieved from http://www.qualitative-research.net/ index.php/fqs/article/view/1908/3447 Accessed in: $10 / 11 / 2019$.

SALLING OLESEN Henning; WEBER, Kirsten. Socialization, language, and scenic understanding. Alfred lorenzer's contribution to a psycho-societal methodology. The Landscape Before and Around Lorenzer (Table 1). Forum: Qualitative Social Research Sozialforschung, 13 (3), setembro, 2012. Retrieved from http:// www.qualitative-research.net/index.php/ fqs/article/view/1906/3443 Accessed in: 10/11/2019

SALLING OLESEN, Henning. The learning subject in life history - a qualitative research approach to learnig. In: ABRAHÃO, Maria Helena Menna Barreto (Org.). A Aventura (auto)biográfica: teoria e empiria. Porto Alegre: EDIPUCRS, 2004. p. 419-463.

SCHÜTZE, Fritz. (1984). Kognitive Figuren des autobiographischen Stegrei`ferzählen. In: KOHLI, Martin; Günther Roberts (Orgs.), Biographie und Soziale wirklichkeit. Stuttgart: Metzler, 1984. p. 78-117.

SOUSA SANTOS, Boaventura de. Epistemologies of the South. Justice against Epistemicide. Boulder, Colorado: Paradigm publishers, 2014.

WEBER, Kirsten. Ambivalens og Erfaring. Mod et kфnsdifferentieret læringsbegreb. Roskilde: Adult Education Research Group/Roskilde University, 1995.

WEBER, Kirsten. Life history, gender and experience: theoretical approaches to adult life and learning. In: Papers presented at the Roskilde University 25th Anniversary Conferences on Life History, Gender and Experience. Roskilde: Adult Education Research Group/Roskilde University, 1998.

WEBER, Kirsten. Læring på livstid? Roskilde: Roskilde Universitetsforlag, 2002.

WEBER, Kirsten; SALLING OLESEN, Henning. Chasing potentials for adult learning: LIFELONG learning in a life history perspective. In: WEBER, Kirsten; SALLING OLESEN, Henning (Orgs.). Zeitschrift fur qualitative bildungs-, beratungs- und sozialforschung. City: Edit House, 2002. p. 283-300.

WEBER, Kirsten; SALLING OLESEN, Henning. Alle disse historier, al denne snak. Livshistori(r) som pædagogisk metode, behagelige kulturstudier eller problematisk realitetsorientering. Dansk Pædagogisk Tidsskrift, (1), 2001a. p. 34-43.

WEBER, Kirsten; SALLING OLESEN, Henning. Space for experience and learning. Theorizing the subjective side of work. In: WEBER Kirsten (Org.). Experience and discourse in professions: a life history perspective. Frederikisberg: Roskilde University Press, 2001b. p. 27-58.

WEINERT, Franz. Concept of COMPETENCE: A conceptual Clarification. In: RYCHEN, Dominique Simone; SALGANIK, Laura Hersh (Orgs.). Defining and Selecting Key Competencies. Seattle/Toronto/Bern/Göttingen: Hogrefe \& Huber, 2001. p. 45-65.

WEINERT, Franz. Vermittlung von Schlüsselqualifikationen. In: MATALIK, Silvia; DIETHARD, Schade (Orgs.). Entwicklungen in aus-und weiterbildung anforderungen, ziele, konzepte. Baden-Baden: Nomos, 1998, s.p.

ZIEHE, Thomas; FORNÄS, Johan; NIELSEN, Elo. Ambivalens og mangfoldighed. København: Politisk Revys forlag, 1989.

Recebido em: 30.09.2019

Aprovado em: 10.02 .2020 
Henning Salling Olesen, professor of lifelong learning, Roskilde University, Denmark. Former chair of ESREA. Editor for European Journal for Research in the Education and Learning of Adults (RELA). Research in adult learning in relation to work, including professional work, using life history method and psycho-societal interpretation, learning theory and experience based learning. E-mail:hso@ruc.dk 